\title{
ROLEX AND APPLE RELATIONSHIP BETWEEN BRAND REPUTATION AND BRAND VALUE CONCEPTS AND TRADEMARK REGISTRATION IN THE CONTEXT OF GLOBALIZATION
}

\section{Aysun KÖKTENER*}

\author{
Sema GÜMÜŞ ${ }^{* *}$
}

\author{
Seda ŞAHAR ${ }^{* * * *}$
}

\begin{abstract}
The brand that constitutes one of the informal elements of businesses; on the one hand, the origin of goods or services, on the other hand, the goods and services of an enterprise to differentiate goods and services from other businesses to perform functions. With the globalization, the brand phenomenon has gained the position of being the most important tool that serves the purposes of increasing the competitiveness of businesses and channeling consumer preferences in the beneficiary position. The brands are important for consumers and intermediaries as well as for consumers. Therefore, the legal protection of the brand; It is important for the brand owners not to experience reputation and financial losses. In the study, the concept of brand, brand value, trademark registration and brand reputation are mentioned and the effects of Apple and Rolex brands on brand reputation and value in the context of globalization were discussed. The methodology of our study is based on comparative case study and content analysis of the two brands that constitute the focus of our research on the basis of specific criteria.
\end{abstract}

Keywords: Brand, Trademark Registration, Brand Reputation, Brand Value

Jel Codes: K0, F0, M30

\section{KÜRESELLEŞME BAĞLAMINDA MARKA ITİBARI VE MARKA DEĞERİ KAVRAMLARI İLE MARKA TESCILİ ARASINDAKİ İLIŞKİ ÖRNEK UYGULAMA ROLEX VE APPLE}

\section{ÖZET}

İşletmelerin gayri maddi unsurlarından birini oluşturan marka; bir yandan mal ya da hizmetlerin kökenini ortaya koyma, diğer yandan da bir işletmenin mal ve hizmetlerinin başka işletmelerin mal ve hizmetlerinden ayırt edilmesini sağlama fonksiyonlarını icra etmektedir. Marka olgusu, küreselleşme ile birlikte işletmelerin rekabet edebilirliğinin artırılması ve faydalanıcı konumdaki tüketici tercihlerinin doğru kanalize edilmesi amaçlarına hizmet eden en önemli araç olma konumunu kazanmıştır. Markalar, üreticiler ve aracılar için olduğu kadar tüketiciler açısından da önemlidir. Bu yüzden de markanın hukuki açıdan korunması; marka sahiplerinin itibar ve maddi kayıplar yaşamaması açısından önem taşımaktadır. Bu çalışmada, marka, marka değeri, marka tescili ve marka itibarı kavramlarına değinilmiş ve Apple ile Rolex markalarının küreselleşme bağlamında, marka tescilinin marka itibarına ve değerine etkileri tartışılmıştır. Çalışmamızın metodolojisi, karşılaştırmalı vaka çalışmasına ve araştırmamızın özel kriterler temelinde odağını oluşturan iki markanın içerik analizine dayanmaktadır.

Anahtar Kelimeler: Marka, Marka Tescili, Marka İtibarı, Marka Değeri

Jel Kodları: K0, F0, M30

\footnotetext{
* DD İstanbul Aydın Üniversitesi, İletişim Fakültesi, Halkla İlişkiler ve Tanıtım Bölümü, Dr. Öğr. Üyesi, aysunkoktener@aydin.edu.tr

** ID İstanbul Aydın Üniversitesi Sosyal Bilimler Enstitüsü, Doktora Öğrencisi, gumussema@gmail.com

*** (D) İstanbul Aydın Üniversitesi Sosyal Bilimler Enstitüsü, Doktora Öğrencisi, sedasahar@hotmail.com
} 


\section{TÜRKIYE MESLEKI VE SOSYAL BILIMLER DERGISI}

Türkiye Mesleki ve Sosyal Bilimler Dergisi, Mayıs 2020, Yıl: 2, Sayı: 3, 64-77.

\section{INTRODUCTION}

As it is known, in the 1970s with the economic crisis, it has shifted from Fordist mode of production to flexible production style and by eliminating the necessity of continuing production depending on certain regions, it allowed the production to be shifted to different regions on a world scale. Due to this development, international capital mobility in the post-1980 period increased to the highest level depending on the development of computer technologies and internet. In this way, the general trend of the world economy has changed with the trends after 1980 and it has been called "globalization" in this change (Atabek, 2008:62).

Trademarks have first emerged in order to show which institution or organization belongs to the product and service. Later, it started to be used with the function of differentiation in order to seperate from its competitors. With this differentiation, brand perception has been created in minds (Batu and Kayacan, 2018:751).

In this study, Apple and Rolex brands' effects on brand reputation and value in the context of globalization are discussed. The reason why the research was limited to the Apple and Rolex brands; As a result of the researches carried out in 2017 and 2018, the brands in question are ranked first in the list of the most reputable and most valuable brands in the world. It focuses on the fact that this feature affects the trademark registration of companies. Quantitative data obtained from the conducted research were subjected to content analysis.

Regarding the two companies, the Turkish Patent and Trademark Authority's World Intellectual Property Organization (WIPO) and the European Union Intellectual Property Office (EIUPO) trademark registration records, which are the Community Trademark Registration System, were examined and the data in the digital media were analyzed on the basis of two companies, It was determined that it was carried out in categories. In this screening, 2439 brands were examined (Turkish Patent, WIPO, EUTM, 2019). The content analysis section of the study was created by examining the criteria included in the scope of the brand, such as the date of registration, the total number of registrations and the number of countries registered, and the numbers obtained are presented in tables.

\section{THE CONCEPT of GLOBALIZATION}

In 1980s, the concept of globalization began to be widely used, but the introduction of the literature to define economic, political and social processes has been found in the 1990s (Ertürk and Şeşen, 2016:8). In the meantime, it is necessary to emphasize that globalization is terminological different and plural. It has different dimensions such as internationalization, mondialisation and globalisation. Globalization refers to the emergence of the world system. This system is beyond the spread of international relations (Cheviron, 2014:25).

When we consider globalization as a process, two terms are important. These points to an important process in the transition of mankind from hunting and collecting to agriculture and industry. Before the human beings consumed ready-made products in nature, then began to consume their own production. After the agricultural and industrial period of the whole world, a new era of communication and Informatics has emerged.

When we consider the reasons for globalization, we need to examine the social and cultural history of mankind. Globalization has affected societies in economic, political, cultural and technological contexts. In short, as we call it today, globalization has gained importance as a result of modernization (Bauman, 2017:8). Looking at the economic dimension of globalization, it is possible to find the first pioneers thanks to clay tablets in previous periods. In these tablets, we can easily see that the distance from the number of merchants during that period was short and they were looking for new ways. In fact, if we call these explorers the secret heroes of globalization, it would be true. In fact, in order to express 


\section{TÜRKIYE MESLEKI VE SOSYAL BILIMLER DERGISI}

Türkiye Mesleki ve Sosyal Bilimler Dergisi, Mayıs 2020, Yıl: 2, Sayı: 3, 64-77.

Journal of Vocational and Social Sciences of Turkey, May 2020, Year: 2, No: 3, 64-77.

globalization as the secret heroes of globalization, Marshall McLuhan used the concept of "global village" in 1964 (Özkul, 2013:120).

The concept of globalization has made the world a single and common market with its economic dimension. Capital, information, goods and services are integrated in a non-boundary relationship. Labor and capital circulate between countries quickly and easily. Globalization, -in an economic sensein addition to a world market horizon, as a result of the enormous expansion of communication in the world is expressed. (Ertürk and Şeşen, 2016:23).

After the second half of the 20th century, however, the concept of globalization based on the past 13 centuries has been one of the most influential factors in economic, technological, social and cultural life since 1980. The effects of globalization on marketing are very important; it has led to the restructuring of marketing since the beginning of the 21st century (Kaplan and Baltacioğlu, 2009:294). With globalization, companies are trying to produce products at world class and try to make their brands a global brand. Because the only condition to compete in the global market is not only producing but branding as well. The main objective of the brand, "differentiation" and "recognition" is to gain competitive advantage through the emotional and beneficial relationship established with the consumer and the customer. The success and management of the brand is defined in line with consumer and potential customers, motives, tastes, preferences, needs and expectations in the target market (Alikişioğlu, 2015:125).

In many studies carried out, the brand's perception of sphericity, the quality and prestige of the brand (Steenkamp et al., 2003:53-65), and the prestige it has brought to the consumer, have been demonstrated in a way to strengthen the consumer's own image with cosmopolitanism, sophistication and modernity (Friedman, 1990:311-328).

\section{AN OVERVIEW of BRAND CONCEPT}

A trademark is a name, term, mark, symbol or design or combination that identifies the goods and services of a company or group of companies and distinguishes its competitors from their goods and services (Kotler, 1997:789). In other words, a trademark is a name, term, sign, symbol, or design to distinguish a business or business group from its competitors to determine the goods and services of a business or business group.

\subsection{Trademark in Marketing and Law}

Brands are the most important factor that adds strength and value to companies. The brand carries more meaning from notation or in terms of operation, it was stated that the nomenclature of products and services. Brand, division of the market, different consumer wishes and requirements to meet different products and brands is an important strategy. The brand is the past and future of a product, gives the product identity and meaning, and beyond that it indirectly establishes an emotional link between the business and the consumer (Hatch and Schultz, 2011:46).

The brand is used to achieve a specific marketing purpose. In simple terms, it is the communication between the consumer and the product by giving the brand, reputation and value to the phrase. Therefore, it is the key that enables consumers to choose between similar quality products or services in the market. The identity of the product and service is the name of the sales (Gümüş, 2014:5-6).

One of the most important indicators of the information-based economy is the increase of symbolic or intellectual property products. At this point, globalization and integration of the world economy have made the brand an important one. In the global economy, a business's goods and services of thousands of competing companies worldwide, goods and services that distinguish the product and service identity gain quality or sought-after standard guarantees a symbol and these properties are now the most important capital of enterprises in the portfolio (Alica, 2008:37). 


\section{TÜRKIYE MESLEKI VE SOSYAL BILIMLER DERGISI}

Türkiye Mesleki ve Sosyal Bilimler Dergisi, Mayıs 2020, Yıl: 2, Sayı: 3, 64-77.

Journal of Vocational and Social Sciences of Turkey, May 2020, Year: 2, No: 3, 64-77.

Today, the development of countries is measured with the importance they give to intellectual and Industrial rights. The most valuable assets of companies are trademarks. Foreign companies see that industrial property rights are not guaranteed as the most important problem. In an economic system of such structural features, increasing competitiveness, branding and, of course, effective protection of industrial rights (Yasaman, 2004:13).

According to the law on industrial property No. 6769, a brand of an enterprise provide goods or services to distinguish the goods or services of other enterprises and brand of protection provided to the owner so they can get a clear and precise understanding of the topic can be shown in the register, provided that the name of the person, including words, shapes, colors, letters, numbers, sounds, and signs can consist of all kinds of goods or packaging with the format (Türk Patent ve Marka Kurumu, 2017:3).

\subsection{Brand Reputation}

Brand reputation refers to the positive or negative value judgments that are revived in the minds of all people about other people, brands and organizations. Reputation management for organizations is becoming more and more important every day. In addition to allocating a certain capital for this business, all brands and institutions that want to be perceived as reputable must plan and establish their infrastructure in a very good way. Infrastructure is the physical fields that the employees and target groups first see. A well-planned working environment is an important step for reputation.

In information societies as a result of today's economic conditions, the reputation of the companies depends on the perception of the social and economic activities they exhibit on the society and in accordance with the new conditions, companies are constantly monitored by the society. Brand reputation is the most important capital of the company. The reputation of the brand can be defined as the effect of various parameters such as quality, usability, functionality and price of the product and service offered by the brand owners on the market by evaluating them in the eyes of the consumer and making the purchase decision. This reputation emerging with the demands and tastes of people is becoming widespread in the society and constitutes the overall reputation of the brand (Kadıbeşegil, 2009:79).

Companies continue their existence, not only according to their turnover and profitability, but also social and environmental problems and they are a part of the solution is connected. Because of the nature of the information society, it is impossible to ignore or ignore the negative effects of an enterprise. Because negative reactions are spreading rapidly, and the image and reputation of the company are at risk (Tosun, 2017:250-251). In this sense, companies' products and services for quality, production, advertising will increase the reputation of the brand with long-term investments earned with brand reputation can make marketing without distress. Additionally, product and service quality by not compromising the brand reputation for a longer period of protection both country and company in the future long-term dynamism can gain.

Consumers' confidence in brands will make reputation easier to build and maintain. For this reason, strong brands can communicate with the target audience more easily. The strength of brand reputation is one of the greatest advantages can brands gain. A brand that has a reputation when it presents a new product to the market, consumers do not recognize it, but prefer it because of the brand reputation that lies behind the trust and confidence in the brand. The communication strategies of the brand, the role of reputation is very important. A reputable brand can communicate with consumers more easily and introduce its products and services more easily. This is the reference that reflects the reputation of the brand from previous products to subsequent products and services (Aula, 2011:29).

\subsection{Brand Value}

With the development of technology, the features of the products and the physical benefits they provide are very similar to each other. It is almost impossible for brands to differentiate from their competitors by using these features. They are successful in the brands sector, which are able to create brand value 


\section{TÜRKIYE MESLEKI VE SOSYAL BILIMLER DERGISI}

Türkiye Mesleki ve Sosyal Bilimler Dergisi, Mayıs 2020, Yıl: 2, Sayı: 3, 64-77.

Journal of Vocational and Social Sciences of Turkey, May 2020, Year: 2, No: 3, 64-77.

by communicating with them in the right direction and differentiating from their competitors in the eyes of target audiences. Brand value is the brand's market power by specifying the firm to provide competitive advantages. The concept of brand value is an interdisciplinary concept. Not only marketing professionals, but finance professionals are also interested in this issue. Therefore, brand value in the minds of consumers a strong brand name and symbol that adds additional value to the consumer and has created a positive impression of the product. This value is to make the market value of the product and the enterprise more valuable than the assets of the enterprise because of the positive impression (Alkibay, 2005:86). The concept of brand value makes the value of the product and the business in the market more valuable than the assets of the business because of the positive impression of the customers (Cop and Bekmezci, 2005:69). A strong brand value in the eyes of businesses, consumers, preferences, sales, profit and market share affects and this situation means that the brand value is affected (Odabaş1 and Oyman, 2002:373).

Brand value in financial terms it can be evaluated if the sale or the replacement of a brand can be defined as the amount of money that must be paid for (Yağl1 and Ünlü, 2016:67). Brands and trademark rights can be expressed with a tangible value can be transferred to others sold when requested for (http://yirmisekiz.net.). The fact that the brands are subject to buying and selling over time reveals the importance of brand value. For example, when a company purchases another entity, the amount that the entity pays more than the sum of its assets represents the amount that it pays to the brand value within the entity. Brand equity is a measure of the value of a brand (Kottler, 1997:800).

Brand value is a concept that includes the disciplines of marketing and finance, it is possible to specify the general accepted definitions of this concept according to both disciplines. Aaker (1991), one of the pioneers of marketing literature, defines the brand as a whole of assets and responsibilities based on brand components that enable enterprises to have more or less value in the face of goods or services produced by other products.

Brand value, which is one of the most important assets of companies, is like the spiritual values of people. Brand value is an important item in the balance sheet, while also offering consumers or the company an advantage of value added and can cause huge losses. Today, the most important way to create value for businesses is to create intangible assets such as brands and patents (Yıldız and Baştürk, 2013:77).

Aaker (1991:15) defines the consumer-based brand value as an abstract asset created by marketing activities as a set of assets and liabilities linked to the distinctive characteristics of the brand, such as name or symbol, which increase or decrease the value of products and services offered to consumers by the enterprise. Keller (1998:2) consumer-based brand value, consumer-owned brand, the brand of the business as well as marketing activities consumers they were different (positive/negative) responses in the form of defined.

\subsection{The Concept of Trademark Registration}

The trademark is an intangible right. It can be thought of as a house of people. For this reason, the brand can be sold (transfer), such as renting (licensing) can be given. The most important thing during the selection of the brand trademark registration the registration of the trademark with the goods or services to be covered is the determination of. The trademark must be different in such a way that it can be distinguished from the trademarks that are not registered or used by others. The first thing to do after the brand selection is to investigate whether the brand is registered or not. After the trademark is registered on behalf of another person, the application for registration of the trademark must be made. In case the trademark is registered on behalf of another, the investment made in case the trademark is registered on behalf of another may be void. According to Turkish patent standards, registration in 45 classes is foreseen. There are sectors in each class. In which classes the trademark registration has been made, the trademark is protected only in those areas of activity. Other areas can not be claimed (Gümüş and Algül, 2018:187). 


\section{TÜRKIYE MESLEKI VE SOSYAL BILIMLER DERGISI}

Türkiye Mesleki ve Sosyal Bilimler Dergisi, Mayıs 2020, Yıl: 2, Sayı: 3, 64-77.

Journal of Vocational and Social Sciences of Turkey, May 2020, Year: 2, No: 3, 64-77.

Trademark registration procedures are completed within 6-7 months on average. If the trademark is renewed within 10 years after the registration, but within 10 years from the date of application, this protection can be extended indefinitely. In order to extend the protection period, a renewal process must be made before the Turkish Patent and Trademark Office. In addition, it should be evaluated that the trademark may be cancelled by the court upon request for the goods which are required to be used in the list of goods written within five years from the date of registration (Gümüş and Algül, 2018:188).

The Madrid Protocol, which regulates the international registration of the trademarks and which Turkey is a party to the Madrid Protocol, provides protection with a single application in all 101 countries or in the selected countries. According to the Madrid Protocol, the International Trademark Registration Authority is the World Intellectual Property Organization in Geneva, Switzerland. (WIPO - World Intellectual Property Office). Registration may, upon request, include some or all of the member states of the Madrid Protocol. The Madrid Protocol is the most preferred trademark registration system because it is advantageous in terms of cost and ease of operation compared to other registration systems (www.wipo.org.).

Applications to be filed from Turkey via Madrid Protocol can only be filed through Turkish patent. It is important to note that the Madrid Protocol is the basis of your application in Turkey. Your registration in Turkey and Madrid Protocol must be the same as the trademark which is the subject of your registration application. In other words, the applicant must use the identical or similar goods or services of the trademark which constitutes the original registration or the original application. Expansion can not be made in goods or services, but the narrowing situation may be in question. There are 101 states parties to the Madrid Protocol. Although there are global countries such as France, Germany, Spain, China, Japan, Russia, Israel and Iran among these countries, they carry out all the procedures related to registration application in English . (www.turkpatent.gov.tr).

Another international trademark application phase, called the European Community Trademark application, came into force on 1 January 1996. In this application, a single trademark application can be obtained in 28 European Union countries. The registration covers all member states of the European community and with the community enlargement it automatically expands to new member states without any effort or expense of the applicant. Community trademark registration is carried out at the community trademarks office (EUIPO) in Alicante, Spain. One of the advantages of the community trademark is that it can be registered in all European countries with a single application. There is no commitment to the trademark in the Office of origin as a trademark application under the Madrid Protocol. It is possible to apply before EUIPO with the desired brand example and classes (www.euipo.europa.eu/ohimportal).

In addition, a company with a surplus of exports to EU member states is making an application for each member state with a single application rather than individual application to these countries and thus it can have more economical costs. The disadvantage of the community trademark is that there is no right to be registered in the requested countries. The processes of all countries depend on each other. Therefore, when your trademark is rejected in one country, it is rejected in other countries. But from another perspective, this issue can also be turned into an advantage. The use of your trademark in one country will be considered to be in use in all countries (Işın and Gümüş, 2019:1).

\subsection{Famous Brand Concept}

In the English language, "well-known", "Marque Notoire" in French, "Bekannte Marke" in German, and "Tanınmış Marka" in Turkish for this concept commonly called Famous brand, well-known brand, really well-known brand, internationally recognized brand, etc. terms are also used (Gümüş, 2014:131).

Industrial Property Law's Article 6/ (4) applications for identical or similar trademarks in the context of Article 1 of the Paris convention for the protection of industrial property shall be rejected in respect of identical or similar goods or services. $6 / 5$ and the same law, item "a brand that is registered or application for registration can be made at earlier date, Turkey has reached in the recognition that due to the level 


\section{TÜRKIYE MESLEKI VE SOSYAL BILIMLER DERGISI}

Türkiye Mesleki ve Sosyal Bilimler Dergisi, Mayıs 2020, Yıl: 2, Sayı: 3, 64-77.

Journal of Vocational and Social Sciences of Turkey, May 2020, Year: 2, No: 3, 64-77.

of an unfair advantage may be provided that the distinctive character or the reputation of the brand could be harmed in situations where they could damage the lining of the same or similar trademark application for registration, the case of resistance to a legitimate reason, without prejudice to the application of the same, similar or different goods or services is made upon the appeal of the owner of the trademark regardless of whether that is dated earlier are denied," the statement is located.

In order to be able to speak of brand recognition in general, it is not necessary to know the brand in question by all those who live in a country and the target group of the brand owner should be based on. Because everyone living in a country is not interested in all kinds of goods and services, it is not appropriate to consider the irrelevant groups in determining the concept of recognition (Dirikkan, 2003:53-54).

Well-known brand in general, known in the relevant circles abroad and in the country of registration minimum, a measure of awareness both within and outside the country increasingly relevant circles and beyond, it is registered in time goods and/or services and to distinguish itself by hanging it next, which has become a quality advertising tool and if used could result in different effects in terms of goods and services that brand (Kaya, 2006:57).

In this context, the reputation and value of the brand has a relationship with the well-known brand. The more reputable or valuable the brand is, the more recognition it is. Because the investment contributes to the reputation of the brand.

\section{RESEARCH}

In this section, the methods of research, sample selection, research hypothesis, data collection method and tool, and finally the findings and evaluation will be given.

\subsection{Method of Research}

Consumers learn to evaluate their product or service choices under the influence of a variety of environmental factors, such as their own experience or promotion advertising and friend groups. In this process, it is aimed to remember the product with this brand and facilitate the purchasing decision process with the brand again by giving a meaning to the Consumer Product Brand. Therefore, in this study, it is aimed to determine the position of the brands according to their registered status within the framework of marketing communication. Accordingly, the study; "within the framework of marketing communication, it will be examined whether brands have created a difference in their registration status and whether they add a financial value to the enterprises. In addition, brand law in terms of origin showing or differentiating the concept of brand will be examined to clarify the issue will be tried. In this study, Rolex and Apple brands, which are among the pioneers of the two sectors of the world and are located in different sectors, were determined. According to the result of the research report to the Reputation Institute in 2017 and Brand Top 100 Most Valuable Global Brands Ranking and Report in 2018 (www.brandz.com/compare; www.reputationinstitute.com), while Rolex was the most reputable brand in the world, Apple was found to be the second most valuable brand in the world. In the study, the effects of Apple and Rolex brands are analyzed on brand reputation, trademark registration and brand value in the context of globalization were discussed. As a result of the examination, the criteria were discussed and interpreted by making comparisons between brands.

\subsection{Selection of Sample}

Rolex, the world's most prestigious, most respected brand, was chosen as the luxury watch company in its annual research conducted in 2017 by the Reputation Institute. The institute has set out 7 parameters and people's perceptions while listing companies. The criteria that determine brand reputation include product and service, innovation, workplace, management, citizenship, leadership and performance. 


\section{TÜRKIYE MESLEKI VE SOSYAL BILIMLER DERGISI}

Türkiye Mesleki ve Sosyal Bilimler Dergisi, Mayıs 2020, Yıl: 2, Sayı: 3, 64-77.

Journal of Vocational and Social Sciences of Turkey, May 2020, Year: 2, No: 3, 64-77.

Rolex was founded in 1905 by Hans Wilsdorf, an expert in clock distribution in London at the age of 24. Hans Wilsdorf equipped the watches with small and very sensitive mechanisms produced by a Swiss watch company in Bienne, considering that the watches could be not only stylish but also reliable.

Table 1. List of Most Reputable Brands Worldwide

\begin{tabular}{|l|l|l|}
\hline LINE & COMPANY & $\mathbf{2 0 1 7}$ REP. POINT \\
\hline 1 & ROLEX & 80,38 \\
\hline 2 & LEGO GROUP & 79,46 \\
\hline 3 & THE WALT DISNEY COMPANY & 79,19 \\
\hline 4 & CANON & 78,28 \\
\hline 5 & GOOGLE & 78,22 \\
\hline 6 & BOSH & 78,13 \\
\hline 7 & SONY & 77,74 \\
\hline 8 & INTEL & 77,74 \\
\hline 9 & ROLLS-ROYCE AEROSPACE & 77.66 \\
\hline 10 & ADIDAS & 77.27 \\
\hline 11 & MICROSOFT & 77.12 \\
\hline 12 & BMW & 76,93 \\
\hline 13 & MICHELIN & 76,75 \\
\hline 14 & LEVI STRAUSS\&CO & 76,70 \\
\hline 15 & NICE INC. & 75,74 \\
\hline 16 & NINTENDO & 75,72 \\
\hline 17 & FERRERO & 75,45 \\
\hline 18 & AMAZON.COM & 75,33 \\
\hline 19 & IBM & 75,29 \\
\hline 20 & APPLE & 74,94 \\
\hline
\end{tabular}

(Source: "Reputation Institute Report, https://www.reputationinstitute.com/sites/default/files/pdfs/2017-Global-RepTrak.pdf)

The brand reputation ranking of companies for 2017 is as shown in Table (1). Rolex in this table $80.38 \%$ while in comparison the other brand Apple taking first place with a score of 74,94\% is ranked with a score of 20.

Apple, however, is one of the top three most valuable brands in the world, as shown in the following table, while Rolex is not included in this ranking. According to the 2018 BrandZ Global Brand assessment report from Millward Brown and WPP, technology companies such as Google, Apple and Amazon are among the top 10 Most Valuable Global Brands on the list. The total brand value of 2018 BrandZ Top 100 is 4.4 trillion dollars. It was found that 21 percent of these brands ' record growth was worth $\$ 750$ trillion, and Apple, which provides 40 percent of its revenue from smart phones, valued $\$ 1$ trillion on the New York Stock Exchange.

Apple Inc. or the old name Apple Computer Inc. headquartered in Cupertino, it is the American multinational company that designs, develops and sells consumer electronics, computer software and personal computers. Most known hardware products are Mac series computers, iPod music player, iPhone smart phone, iPad tablet computer and Apple Watch. Its software includes OS X and iOS operating systems, iTunes media browser, Safari Internet Browser, and iWork packages. The company was founded on April 1, 1976, and on January 3, 1977, Apple Computer, Inc. it has become an incorporated company by its name. The word "computer" in its name was removed on January 9, 2007 with the introduction of iPhone to reflect their orientation to consumer electronics. Apple is the world's second largest information technology company in terms of revenue after Samsung Electronics; the third largest mobile phone manufacturer in the world after Samsung and Nokia. Fortune Magazine described Apple as the most popular company in the United States in 2008 and worldwide from 2008 to 2012. In addition to Apple's app store and iTunes store online stores as of November 2012, there are 394 retail stores in 14 different countries. In terms of stock market value, Apple has become the world's most valuable company since September 2012. 


\section{TÜRKIYE MESLEKI VE SOSYAL BILIMLER DERGISI}

Türkiye Mesleki ve Sosyal Bilimler Dergisi, Mayıs 2020, Yıl: 2, Sayı: 3, 64-77.

Journal of Vocational and Social Sciences of Turkey, May 2020, Year: 2, No: 3, 64-77.

Table 2. Brand Top 100 Most Valuable Global Brands in 2018

\begin{tabular}{|c|c|c|c|c|}
\hline COMPANY & SECTOR & 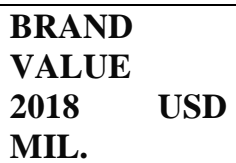 & $\begin{array}{l}\text { CHANGE } \\
\text { VALUE } \\
\text { 2018-2017 }\end{array}$ & COUNTRY \\
\hline Google & TECHNOLOGY & 302,063 & $+23 \%$ & USA \\
\hline & TECHNOLOGY & 300,595 & $+28 \%$ & USA \\
\hline amazon & SALES & 207,594 & $+49 \%$ & USA \\
\hline Microsoft & TECHNOLOGY & 200,987 & $+40 \%$ & USA \\
\hline Tencent腾讯 & TECHNOLOGY & 178,990 & $+65 \%$ & CHINA \\
\hline facebook & TECHNOLOGY & 162,106 & $+25 \%$ & USA \\
\hline VISA & FINANCE & 145,611 & $+31 \%$ & USA \\
\hline Mcon & FOOD & 126,044 & $+29 \%$ & USA \\
\hline $22^{\text {Alibaba Group }}$ & SALES & 113,401 & $+92 \%$ & CHINA \\
\hline$\underbrace{=}_{\text {AT\&T }}$ & TELECOM & 106,698 & $-7 \%$ & USA \\
\hline
\end{tabular}

\subsection{Data Collection Method and Tool}

Within this scope, the methodology of our study is based on a comparative case study and a content analysis of the two brands that constitute the focus of our research on the basis of specific criteria. Content analysis method will be used in accordance with the purpose of the research. Content analysis is a process of digitizing certain characteristics of a particular text, a book, a document (Karasar, 1999:184). It seems that the purpose of content analysis is not to describe and explain a text, but to draw conclusions about social reality from the content of the text (Gökçe, 2001). In today's applications, content analysis is done in two main types depending on the purpose. These are field surveys and the analysis of the meaning of the message (Aziz, 2014:135).

The trademark registration of the Turkish Patent and Trademark Office, WIPO trademark registries, European Union Intellectual Property Office (EUIPO) trademark registries of 28 European countries have been examined and the data contained in the digital environment have been examined on the basis of two companies and it has been determined in which countries the number of trademark registries is registered. Turkish patent, WIPO, EUIPO 2.439 trademarks have been examined in this screening. The first registration date in Turkey and in other countries, the number of registrations, and the numbers obtained from the criteria such as the countries covered by the protection are shown in the table in the content analysis of the study.

The research questions identified in the scope of the above-mentioned research objective and methodology are determined in the following form.

Research Question 1: Registration of a trademark or brand will affect brand reputation in excess of the number value?

Research Question 2: Does the old trademark registration date affect brand reputation and brand value?

Research Question 3: Does the fact that brands are registered in many countries affect brand reputation and brand value? 


\section{TÜRKIYE MESLEKI VE SOSYAL BILIMLER DERGISI}

Türkiye Mesleki ve Sosyal Bilimler Dergisi, Mayıs 2020, Yıl: 2, Sayı: 3, 64-77.

Journal of Vocational and Social Sciences of Turkey, May 2020, Year: 2, No: 3, 64-77.

\subsection{Findings and Evaluation}

In the case of an unregistered trademark, the owner of the registered trademark shall be entitled to prohibit the use of the registered trademark in accordance with the provisions of the preceding paragraph. The nature of status determination, in the study, the concepts of brand image and brand equity should be considered together in conjunction with the registration of a trademark under the assumption that the concepts have been set out.

Table 3. Examining The Total Number of Companies' Trademark Application and Trademark Registration:

\begin{tabular}{|l|l|l|l|}
\hline BRAND & EUIPO & TURKEY & WIPO \\
\hline ROLEX SA & 18 & 71 & 64 \\
\hline APPLE INC & 914 & 671 & 701 \\
\hline
\end{tabular}

Table 4. Examination of The Registration Numbers of Apple and Rolex Trademarks:

\begin{tabular}{|l|l|l|l|}
\hline BRAND & EUIPO & TURKEY & WIPO \\
\hline ROLEX & 18 & 29 & 57 \\
\hline APPLE & 89 & 72 & 65 \\
\hline
\end{tabular}

The trademark registration of the Turkish Patent and Trademark Office, WIPO Romarin section, where international trademark registration transactions were made within the framework of Madrid Protocol, and the content analysis of the trademark registration of the European Union Intellectual Property Office Trademark Office where the European Community trademark registration application was made were obtained in Table-3. As shown in Table 3, the maximum number of trademark registrations in three categories is Apple Inc. it has been determined that it belongs. As indicated in Table 4, the maximum number of registered trademarks is Apple Inc. it appears to belong. It is believed that the number of trademark registries is not an issue that affects the brand reputation, the number of registries of the brand is more than an element that affects the brand value. As it is known, the trademark is an intangible right and it is like a car, house, factory building. For this reason, the brand is located in the Fixed Assets section of the balance sheet of the companies. The excess of the brand refers to the excess of the company's assets, which increases the value of the company and hence the brand. In the case of a trademark infringement, the owner of the registered trademark shall be liable to the owner of the registered trademark for the same or similar goods or services as the owner of the registered trademark. as a response to research question No. 1, it has been determined that companies do not influence brand reputation but have an impact on the value of their brands. Brand reputation, product and service quality is shaped on the basis of the beginning should not be forgotten. However, there will be a greater risk of counterfeiting a valuable trademark than reputation. Because the distinguishing power of the strong and well-known brands will be utilized. Powerful and well-known brands if the issue is purely a financial situation you are dealing with is directly linked to the value of the brand. It should be noted that if the registration of the trademark is completed, it will result in an increase in the value of the trademark in the eyes of the consumer protected from counterfeiting. The labor, investment and effort spent to create a valuable brand is an important and indispensable value for both the country and the world.

Table 5. Examination of The First Registration Dates of Apple and Rolex Trademarks

\section{BRAND}

ROLEX

APPLE

\section{EUIPO}

10.01.2000

\section{TURKEY}

27.10.1967

28.11 .1983

\section{WIPO}

07.12 .1948

According to Table-5, the oldest in the history of the brand is the Rolex. Rolex, founded in Switzerland in 1905, registered its first in the world on 12/7/1948. It was determined that the first registration of the company in Turkey was dated 10/27/1967. However, although Apple Inc., the phone and computer giant, was founded on the date of 1976, the world's first registration was made on 10/10/1968. According to Rolex, the registration in Turkey is about 16 years later. The reason for this is that it is thought that 


\section{TÜRKIYE MESLEKI VE SOSYAL BILIMLER DERGISI}

Türkiye Mesleki ve Sosyal Bilimler Dergisi, Mayıs 2020, Yıl: 2, Sayı: 3, 64-77.

Journal of Vocational and Social Sciences of Turkey, May 2020, Year: 2, No: 3, 64-77.

the information and technological developments in Turkey will be followed a little bit later along with the political reasons. However, one of the reasons for the registration of both companies to EUIPO in Turkey and WIPO in the late date was that EUIPO was established in 1996. Therefore, as soon as it was established, Apple made its first registration and on 01/10/2000, it made a Rolex registration application and protected its trademark in $28 \mathrm{EU}$ member states. As is known, brand awareness is in parallel with the old brand. The older the brand, the more the brand is adopted in the consumer. The common recognition of the brand indirectly adds value and reputation to the companies by enabling them to be recognized. In this case, it is not possible to establish a similarity between the number of registered trademarks and the number of registered trademarks. According to the above-mentioned findings, "does the registration date of the trademark affect the brand reputation and brand value? as a response to research question No. 2, it has emerged that the history of brand applications of companies adds value and reputation to the companies.

Table 6. Examination of The Number of Countries Where Apple and Rolex Trademarks Are Registered

\begin{tabular}{|ll|}
\hline BRAND & THE NUMIBER OF COUNTRIES \\
\hline ROLEX & 100 \\
\hline APPLE & 96 \\
\hline
\end{tabular}

Today, with increasing competition conditions, companies have to strengthen their position in the market. However, brand owners are obliged to expand towards new markets according to the developments and technology in the current market. Therefore, the geographical expansion of the brand is important. Because global brands are usually successful brands and have a certain reputation. With globalization, they want to be in fast competition in the world markets. In this context, both Rolex and Apple consumers strive to gain quality and status beyond selling watches or computer/phone brands. People who buy these branded products have the feeling that they feel special as well as prestigious and privileged. In this sense, in order to become a brand in the world markets, we have to establish scientific elements such as creating added value and creating a modern marketing network as well as producing new and original products. Because it is the "branding era", depending on the design and R \& D-oriented development strategy. According to Table 6, the number of countries in which it is registered is most Rolex. Rolex is registered in 100 countries around the world. Apple is registered in 96 world countries with only 4 countries missing. These two brands are known for their R \& D and their designs by providing the brand's recognition through these two features. A brand name is a brand name that refers to a specific type of brand. Therefore, the fact that a trademark is registered in multiple countries has increased the value of the trademark in parallel with its reputation. The purpose of registering the trademarks in many countries is to monopolize the imitation by providing the legal protection of the trademarks. Because the protection of the trademark is national, and the country in which it is registered is protected there. Therefore, customers at those borders are known for their brand. In other countries like this, brand name means to create a dynamic environment by giving energy to the brand and to obtain new customers.

When this is considered economically, the trademark registration is an investment and provides longterm intangible gains and guarantees the company's success. In addition, by increasing brand awareness and value, it gives global brand image from the local brand. Thanks to the trademark registration, it ensures its progress in efficient and sound steps. Trademark registration is a legal process and it is an important process in the name of being registered with legal sanctions. Because the economic value of today's industry is measured by intellectual capital rather than physical assets. In other words, brands among intellectual assets are now "measured". Thus, the awareness of being among the trademarks of the world trade by protecting the brands created by spending great time, effort and money has been formed. In this regard, "does the fact that trademarks are registered in many countries affect the brand's reputation and brand value?" as a response to research question No. 3, it has been determined that companies have influence on brand reputation as well as the value of their brands. 


\section{TÜRKIYE MESLEKI VE SOSYAL BILIMLER DERGISI}

Türkiye Mesleki ve Sosyal Bilimler Dergisi, Mayıs 2020, Yıl: 2, Sayı: 3, 64-77.

Journal of Vocational and Social Sciences of Turkey, May 2020, Year: 2, No: 3, 64-77.

\section{RESULT}

With developing technology, globalization has made the world a single and common market with its economic dimension. Globalization, in other words, is considered to be the main slogan for integration into the world today. With globalization, companies are trying to produce products at world class and try to make their brands a global brand. In this sense, businesses want to globalize their products. Brand image and value in order to take advantage of global products are willing to become a global brand. The meaning consumers identify with the global brand is high and the value they understand is very high.

Global brands' reputation or values are high. However, there are various factors for global brands to be able to become global brands and certain conditions. For this purpose, enterprises operating at global level should establish their trademark registrations on a solid basis. In order to establish the basis of the trademark, the business must be started by registering the trademark. However, the trademark registration is considered to be one of the financial value items according to a philosophy according to some, but in fact, trademark registration is a "source of expertise" for a company. Thus, companies will determine their brands in the first place and investigate on their registrability and prevent accidents that may occur later. In order to be able to compete in the international arena, brands in the leading position in the country will want to take part in the markets of other countries. A trademark is a registered trademark of a country in which the trademark is registered. This registration will serve as a kind of confidential advertising by ensuring the brand's awareness in other countries over time.

Taken up as a case study this description within the scope of the Rolex brand with the concepts of brand reputation and the brand value of Apple and Turkish patent institution and WIPO and trademark authorities in the eyes of the International and Ecuador, in the words of trademark registration were surveyed about the number. The data obtained from these research results and the research questions in the study were formed and these questions were answered. The research questions interpreted in the study are based on the number of criteria determined and if these criteria are increased, the number of research questions can be increased, and more detailed studies can be done in the field.

On the other hand, within the scope of the data obtained in the research, it has been determined that there are 104 registered brands with Rolex inscriptions and 226 registered brands with APPLE inscriptions. Although the number of Rolex brand is less than the number of APPLE brand, ROLEX brand is more reputable. The main reason for this is that the registration of the ROLEX brand is almost a century old. Depending on the concept of time, which is a criterion of reputation, it is concluded that the old brand contributes to the brand's reputation. As stated in our research, it is thought that the high number of registrations of the trademark is a factor affecting the brand value. Therefore, one of the reasons APPLE is the second most valuable brand in the world is the high number of registrations. Because the brand is an intangible right and is included in the fixed assets of companies in the balance sheet. The high number of registration numbers of the brand indicates the excess of the company's securities, which is a factor that increases the value of the company and therefore the brand.

In order to become a global brand and create more added value, the spread of the brand, in other words, the number of countries where the brand exports and is registered is an important parameter. The fact that the Rolex brand is registered in 100 countries increases the reputation of the brand and also affects its reputation. The purpose of registering brands in many countries is to prevent counterfeits. Due to the low quality of counterfeit branded products, the brand loses its reputation in the eyes of the consumer. This not only affects brand reputation but also affects its brand value negatively.

As a result, in the context of globalization there is a relationship between brand reputation and brand equity with the concepts of trademark registration, and to effectively manage this relationship over time, and in this way to increase the value and credibility of the brands they have, but also to gain a competitive advantage in the global market in the national market of companies who want to give importance to the legal protection of trademarks trademark registration procedures, will be one of the healthy methods. 


\section{REFERENCES}

Aaker, A. D. (1991). Managing Brand Equity: Capitalizing On Vaule Of A Brand Name, New York: The Free Maxwell Macmillan International.

Alıca, T. (2008). Markanın Hukuki Ve Cezai Koruması, İstanbul: İstanbul Barosu Yayınları.

Alikişioğlu, M. (2012). Reklamın İyisi, İstanbul: Optimist Yayınları.

Alkibay, S. (2005). "Marka Değeri Ve Profesyonel Spor Kulüplerinin Taraftar İlişkileri Yoluyla Marka Değeri Yaratmaları Üzerine Bir Araştırma", Hacettepe Üniversitesi İktisadi Ve İdari Bilimler Fakültesi Dergisi, 23(1), 83-108.

Atabek, G. Ş. (2008). “Globalleşme Ve Görüntü Pazarı: Dijital Görüntü Bankaları”, Galatasaray Üniversitesi İletişim Dergisi, 59-77.

Aula, P. (2011). Meshworked Reputation: Publicists' Views On The Reputational İmpacts Of Online Communication. Public Relations Review, 37(1), 28-36.

Aziz, A. (2014). Sosyal Bilimlerde Araştırma Yöntemleri Ve Teknikleri, Ankara: Nobel Akademik Yayıncılık.

Batu, M. and Kayacan, Ş. (2018). "Kurumsal İletişim Projelerinin, Kurumların Marka Algısı İle İlişkisi: Belediyelere Yönelik Bir Analiz”, Erciyes Üniversitesi İletişim Dergisi 4 (5), 749-769.

Bauman, Z. (2017). Kürselleşme, (Çev:Abdullah Yılmaz), İstanbul: Ayrıntı Yayınları.

Brandz (2018). "Brand Top 100 Most Valuable Global Brands Ranking And Report", Https://Www.Brandz.Com/Admin/Uploads/Files/Bz_Global_2018 D1.Pdf, Date Of Access: 26.03.2019.

Cheviron, N. T. (2014). Küresel İletişim, İstanbul: Ekslibris Yayınları.

Cop, R. and Bekmezci, M. (2005). "Marka Ve Bilinirliliği Yüksek Markalı Çamaşır Deterjanı Üzerine Bir Uygulama”, Ticaret Ve Turizm Eğitim Fakültesi Dergisi, S1, 66-83.

Dirikkan, H. (2003). Tanınmış Markanın Korunması, Ankara: Seçkin Yayıncılık.

Euipo (2019). Https://Euipo.Europa.Eu/Ohimportal/, Date Of Access: 20.01.2019.

Ertürk, K. Ö. and Şeşen, E. (2016). Küreselleşen Dünyada Halkla İlişkiler Ve Uzlaşı, İstanbul: Kutupyıldızı Yayınlar1.

Friedman, J. (1990). Being in the World: Globalization and Localization, Theory Culture and Society, 7(2-3), 311328.

Gökçe, O. (2001). İçerik Çözümlemesi, Konya: Selçuk Üniversitesi Yayınevi.

Gümüş, S. and Algül, A. (2018). "Pazarlama İletişimi Bağlamında Markanın Tescili Sonrası Konumu: Eti, Ülker Ve Torku Örnekleri”, İstanbul Aydın Üniversitesi Yeni Medya Elektronik Dergisi, (2)3, 183-195.

Gümüş, S. (2014). Markaların Ulusal Düzlemde Yaratılması, Korunması Süreci Ve Örnek Uygulamalar, İstanbul Kültür Üniversitesi Sosyal Bilimler Enstitüsü Yayımlanmamış Yüksek Lisans Tezi, İstanbul.

Hatch, M. J. and Schultz, M. (2011). Marka Girişimi, İstanbul: Brandage.

Işın, F. B. and Gümüş, S. (2019). Markanın Yol Haritası, Ankara: Siyasal Kitabevi.

Kadıbeşegil, S. (2009). İtibar Yönetimi, İstanbul: Kapital Medya.

Kaplan, M. D. and Baltacioğlu, T. (2013). Küresel Markalama Stratejileri, (Editörler), Necdet Timur Ve Alparslan Özmen. Stratejik Küresel Pazarlama, Ankara: Efil Yayınevi, 294-311.

Karasar, N. (1999). Bilimsel Araştırma Yöntemi, Ankara: Nobel Yayın Dağıtım.

Kaya, A. (2006). Marka Hukuku, İstanbul: Arıkan Basım Yayım Dağıtım.

Keller, K. L. (1998). Strategic Brand Management: Building, Measuring, And Managing Brand Equity, Boston: Prentice Hall International.

Kotler, P. (1997). Marketing Management, New Jersey: Prentice Hall International Inc.

Odabaşı, Y. and Oyman, M. (2002). Pazarlama İletişim Yönetimi, İstanbul: Mediacat.

Özkul, O. (2013). Kültür Ve Küreselleşme, İstanbul: Pınar Yayınları.

Reputation Institute (2017). "The World's Most Reputable Https://Www.Reputationinstitute.Com/Sites/Default/Files/Pdfs/2017-Global-Reptrak.Pdf )

Steenkamp, J. B. E., Batra, R., \& Alden, D. L. (2003). How Perceived Brand Globalness Creates Brand Value, Journal of International Business Studies, 34(1), 53-65.

Tosun, B. N. (2017). Marka Yönetimi, İstanbul: Beta Yayınları.

Türk Patent Ve Marka Kurumu (2017). "Sınai Mülkiyet Kanunu”,

Https://Www.Turkpatent.Gov.Tr/Turkpatent/, Date Of Access: 03.01.2019.

Wipo (2019). Https://Www.Wipo.İnt/Portal/En/Index.Html, Date Of Access: 03.02.2019.

Yağlı, İ. and Ünlü, U. (2016). “Corporate Governance And Brand Value”, European Journal Of Business And Management, 8(15), 65-73.

Yasaman, H. (2004). Marka Hukuku İle İlgili Makaleler, Hukuki Mütalaalar, İstanbul: Vedat Kitapçılık. 


\section{TÜRKIYE MESLEKI VE SOSYAL BILIMLER DERGISI}

Türkiye Mesleki ve Sosyal Bilimler Dergisi, Mayıs 2020, Yıl: 2, Sayı: 3, 64-77.

Journal of Vocational and Social Sciences of Turkey, May 2020, Year: 2, No: 3, 64-77.

Yavuz, L., Alıca, T., Baykara Ş. Y. (2018). Sınai Mülkiyet Kanunu. Ankara: Seçkin Yayıncılık.

Yıldız, S. and Baştürk, F. (2013). "Kars İli Marka Varlıklarının Tüketici Temelli Değer Ölçümü Araştırması”, Çağdaş Yerel Yönetimler, 22(4), 75-90.

Yirmisekiz.Net (2019). Http://Yirmisekiz.Net/Category/Hukuk/Fikri-Mulkiyet-Hukuku/, Date Of Access: 10.01.2019. 